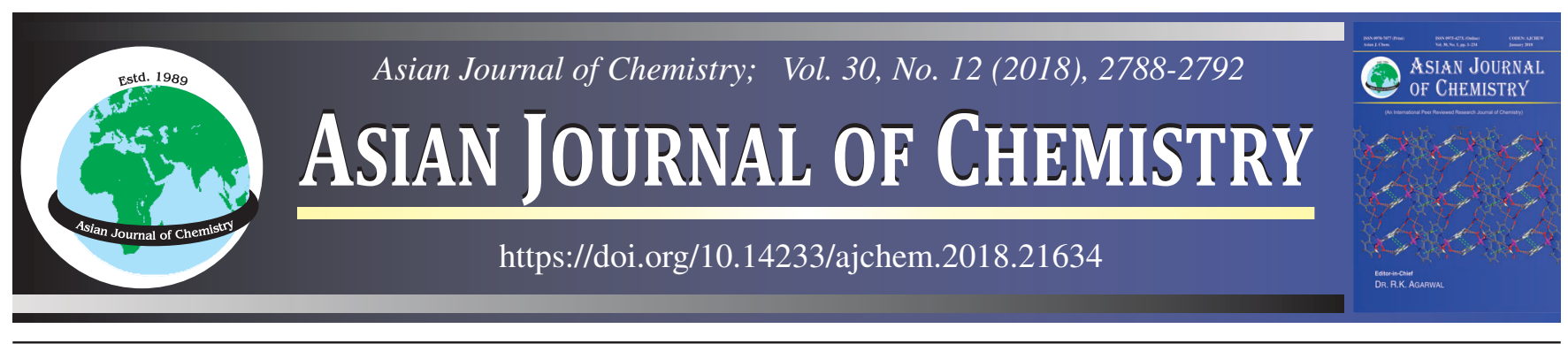

\title{
Synthesis and Characterization of New Theophylline and \\ Chlordiazepoxide Prodrug Polymers based on Maleimide
}

\section{Layali Abdullah Abbas and Mohanad Mousa Kareem*}

Department of Chemistry, College of Science, University of Babylon, P.O. Box 4, Hilla, Iraq

*Corresponding author: E-mail: mohanad_1972@yahoo.com

Received: 6 August 2018;

Accepted: 20 September 2018;

Published online: 31 October 2018;

AJC-19149

\begin{abstract}
In this work, two new drug substituted monomers and new homogenous and heterogeneous polymers were synthesized which loaded with medicinal properties to extend the controlled drug. The first step includes the preparation maleimic acid (L1) and (L2) via reaction of maleic anhydride with 5-amino salicylic acid. Then compound L2 was converted to its corresponding acyl chloride derivative which reacted with amino drugs (theophylline and chlordiazepoxide, afforded L3 and L4 monomers, respectively. Homogeneous polymers (L5 and L6) prepared through polymerization reaction of free radicals of monomers (L1) and (L2) under nitrogen atmosphere using methyl ethyl ketone peroxide (MEKP) as initiator. Heterogeneous polymers (L7 and L8) prepared through polymerization reaction of free radicals of monomers ( $\mathbf{L} 1$ and $\mathbf{L 2}$ ), separately with acrylic acid under nitrogen atmosphere using MEKP as initiator. All these prepared monomers and polymers were characterized by FTIR, ${ }^{1} \mathrm{H}$ NMR and ${ }^{13} \mathrm{C}$ NMR. Controlled drug release and swelling \% was studied in different $\mathrm{pH}$ values at $37^{\circ} \mathrm{C}$. Intrinsic viscosities were measured at $25{ }^{\circ} \mathrm{C}$ with Ostwald viscometer and applied the characteristic of solubility for these polymers and studied the biological activities.
\end{abstract}

Keywords: Homopolymerization, Heteropolymerization, Swelling, Drug delivery system.

ᄂ

\section{INTRODUCTION}

Maleic anhydride is a chemical compound, which used in several applications of industrial chemistry [1]. Maleic anhydride structure contains two acidic carbonyl groups and a double bond and can be easily polymerized in the presence of free radical catalysts as well as under gamma and UV radiations [2-4].

Maleimides derivatives prepared from maleic anhydride by treatment with amines followed by dehydration [5], where $\mathrm{N}$-substituted maleimides are prepared from the amino group is replaced with alkyl or aryl groups, respectively followed by ring closure to produce $\mathrm{N}$-substituted maleimide [6]. While, $\mathrm{N}$-phenylmaleimide prepared from the reaction of maleic anhydride with aniline in ethyl ether at room temperature [7]. Maleimides have been polymerized by addition polymerization with either free radical or anionic initiation.

Prodrug polymers are drug molecules held in polymer molecules act as drug delivery system. Polymer drugs have been used in various bioactive applications [8] and therefore they may become a feasible cure for endocrine-related cancers [9]. These polymers are defined to be sensitive to specific enzymes that are visible in diseased tissue, the drugs are remained attached to the polymer until the enzymes are associated with the diseased tissue are present and this process remarkably decreased the damage to healthy tissue [9].

Lately, assorted drug delivery techniques are being advanced like alteration of the actual drug or conjugations of the drug to another carrier molecules and the polymer prodrug synthesis has been swiftly growing technique [10]. Prodrugs involve the integration of drug molecules with the carrier molecule, thus the integration of a drug molecule with a polymer forms a polymeric prodrug [11]. Different polymers have been synthesized and used as carrier molecules in which the drug molecule can be implanted [12].

The prodrug molecules contains drug and polymeric backbone, targeting group, spacer and solubilizing agent where each component has a specific important role to play for the drug action. The used polymeric backbone can be biodegradable or inert in action, while the spacer utilized for indicating

This is an open access journal, and articles are distributed under the terms of the Creative Commons Attribution-NonCommercial 4.0 International (CC BY-NC 4.0) License, which allows others to copy and redistribute the material in any medium or format, remix, transform, and build upon the material, as long as appropriate credit is given and the new creations are licensed under the identical terms. 
the target site and the rate at which the drug is being released from the prodrug which can be either through hydrolysis or enzymatic action $[13,14]$.

In order to examine the possibility of obtaining better polymers from $N$-substituted maleimide, we reported here the synthesis of $N$-[5-salicylic maleimide] monomer and its polymerization and co-polymerization with acrylic acid. The physical, spectral and thermal properties have been studied to characterize the homo- and co-polymers.

\section{EXPERIMENTAL}

The densities of polymer samples were determined at 25 ${ }^{\circ} \mathrm{C}$ by the displacement method with a single stem pycnometer $[15]$ using water as non-solvent. The intrinsic viscosity $(\eta)$ measurements were carried out in acetone at $30^{\circ} \mathrm{C}$ using an Ostwald viscometer suspended level viscometer. The IR spectra measurements were recorded using a device Fourier Trans Infrared Spector Promoter-Shimadzu within range $\left(4000-400 \mathrm{~cm}^{-1}\right) .{ }^{1} \mathrm{H}$ NMR was taken at $300 \mathrm{MHz}$ in DMSO- $d_{6}$ on a VXR-300 spectrometer. Tetramethylsilane was used as reference. ${ }^{13} \mathrm{C}$ NMR spectra were recorded at 75.5 MHz in DMSO- $d_{6}$ on Bruker-300A spectrometer. Starting chemical compounds were obtained from Fluka or Aldrich.

Synthesis of maleimic acid $\left(\mathbf{L}_{1}\right)$ : Mixture of maleic anhydride (1.0 g, 0.002 mmol.) with 5-aminosalicylic acid (0.7g, 0.005 mmol.) was heated gently with constant stirring for $30 \mathrm{~min}$. Then the entire reaction mixture was cooled externally. The greenish yellow solid 5-aminosalicylic maleimic acid was filtered and dried at $50{ }^{\circ} \mathrm{C}$ afforded greenish yellow compound $\mathbf{L}_{1}$ having molecular formula $\mathrm{C}_{11} \mathrm{H}_{9} \mathrm{NO}_{6}$, yield: $93 \%$, m.p. 191 $-194^{\circ} \mathrm{C}[16,17]$. It was recrystallized from methanol. IR $(\mathrm{KBr}$, $v_{\max }, \mathrm{cm}^{-1}$ ): 3307 (OH alcohol), 3500 and 2500 (OH carboxylic acid), 1677 ( $\mathrm{C}=\mathrm{O}$ in a six membered imide ring), $1526(\mathrm{C}=\mathrm{O}$ carboxylic acid), 1484 and 1447 (C=C, arom.), 1377 (C-H bend.), 1191 (C-N str.), 846 (cis-CH=CH phenyl ring). ${ }^{1} \mathrm{H}$ NMR (300 MHz, TMS, $\delta$ ppm): 4.14 (s, H, OH), 6.43, 6.98 ( 2H, HC=CH), 7.15 (s, H, Ar-H), 7.69 (s, H, Ar-H), 7.86 (s, H, Ar-H), 8.15 (s, H, N-H), 10.41(H, COOH), 10.57 (H, COOH), ${ }^{13} \mathrm{C}$ NMR (300 MHz, TMS, $\delta$ ppm): 142.859 (2C, HC=CH), 112.897 (C, C-OH), 133.321 (6C, Ar-C), 117.233, 157.590 $(\mathrm{C}, \mathrm{N}-\mathrm{C}=\mathrm{O}), 162.959(\mathrm{C}, \mathrm{COOH}), 166.668$ (C, COOH). Elemental anal. calcd. (found) \% for $\mathbf{L}_{1}$ : C, 52.69 (52.68); H, 3.59 (3.60); N, 5.58 (5.60).

Synthesis of 5-salicylic maleimide $\left(\mathbf{L}_{2}\right)$ : Maleimic acid $\left(\mathbf{L}_{\mathbf{1}}\right)$ $(0.5 \mathrm{~g}, 0.1 \mathrm{~mol})$, sodium acetate $(0.326 \mathrm{~g}, 0.2 \mathrm{~mol})$ and $5 \mathrm{~mL}$ acetic anhydride in $5 \mathrm{~mL}$ of DMF were mixed and reacted for $2 \mathrm{~h}$ at $45^{\circ} \mathrm{C}$. The cooled mixture was poured into crushed ice. Yellow needles of 5-salicylic maleimide was filtered, washed with $5 \% \mathrm{NaHCO}_{3}$ solution and dried at $55^{\circ} \mathrm{C}$ for several hours. The product was further recrystallized from chloroform afforded black (viscous) compound $\mathbf{L}_{2}$ having molecular formula $\mathrm{C}_{11} \mathrm{H}_{7} \mathrm{NO}_{5}$; yield: $91 \%$. IR ( $\left.\mathrm{KBr}, v_{\max }, \mathrm{cm}^{-1}\right): 3287$ (OH alcohol), $3106(\mathrm{C}-\mathrm{H}), 2982$ and $2918(\mathrm{C}-\mathrm{H}), 1709(\mathrm{C}=\mathrm{O}$ in six membered imide ring), 1663 ( $\mathrm{C}=\mathrm{O}$ amide), 1553 and 1492 ( $\mathrm{C}=\mathrm{C}$, arom.), 1439 (C-H bend.), 1288 (C-N str.), 827(phenyl ring). ${ }^{1} \mathrm{H}$ NMR (300 MHz, TMS, $\delta$ ppm): 5.70 (s, H, OH),7.51-8.71 (m, 3H, Ar-H), 6.8-7.30 (d, 2H, HC=CH), 10.56 (s, H, COOH). ${ }^{13} \mathrm{C} \mathrm{NMR}$ (300 MHz, TMS, $\delta$ ppm): $29.649\left(\mathrm{C}, \mathrm{CH}_{3}\right), 31\left(\mathrm{C}, \mathrm{CH}_{3}\right), 45.648$
(C, C-OH), 106.387-147.024 (6C, Ar-C), 151.176 (2C, N-C=O), 160.275 (2C, N-C=O), $166.711(\mathrm{C}, \mathrm{N}-\mathrm{C}=\mathrm{O})$. Elemental anal. calcd. (found) \% for $\mathbf{L}_{2}:$ C, $56.65(56.68) ; \mathrm{H}, 3.00(3.01)$; N, $6.00(8.98)$.

Synthesis of monomer drugs $\left(\mathrm{L}_{3}\right.$ and $\left.\mathrm{L}_{4}\right)$ : 5-Salicylic maleimide $\left(\mathbf{L}_{2}\right)$ (1 mmol, $0.2 \mathrm{~g}$ ) is added to $3 \mathrm{mmol}$ of triethylamine $\left(\mathrm{Et}_{3} \mathrm{~N}\right)$ in $10 \mathrm{~mL}$ of DMSO, then $1 \mathrm{mmol}$ of $\mathrm{SOCl}_{2}$ is added at room temperature. It was then added $(1 \mathrm{mmol})$ of drugs (theophylline and chlorodiazepoxide) and left for $(0.5 \mathrm{~h})$, cooled reaction mixture was poured crushed ice, left for $0.5 \mathrm{~h}$. Finally the black product was filtered and crystallized from dichloromethane (Scheme-I).

Compound $\mathrm{L}_{3}$ : m.f. $\mathrm{C}_{18} \mathrm{H}_{13} \mathrm{O}_{6} \mathrm{~N}_{5}$, m.p. $210-212{ }^{\circ} \mathrm{C}$, yield $59 \%$. IR (KBr, $\left.v_{\max }, \mathrm{cm}^{-1}\right): 3287$ (OH alcohol), $3106(\mathrm{C}-\mathrm{H}$ bend. $\left.s p^{2}\right), 2982$ and 2918 (C-H bend. $\left.s p^{3}\right), 1709(\mathrm{C}=\mathrm{O}$ in six membered imide ring), 1663 ( $\mathrm{C}=\mathrm{O}$ amide), 1553 and $1492(\mathrm{C}=\mathrm{C}$, arom.), 1439 (C-H bend.), 1288 (C-N str. phenyl ring). ${ }^{1} \mathrm{H}$ NMR (300 MHz, TMS, $\delta$ ppm): 6.60 (s, H, OH), 7.30-7.90 (m, 3H, Ar-H), 6.90-7.20 (d, 2H, HC=CH), 9.80 (s, H, C=CH), 3.12 (s, 3H, $\mathrm{CH}_{3}$ ), 3.60 (s, 3H, $\mathrm{CH}_{3}$ ), 1.2 (ethanol solvent), 2.5 (DMSO). ${ }^{13} \mathrm{C} \mathrm{NMR}(300 \mathrm{MHz}, \mathrm{TMS}, \delta \mathrm{ppm}): 29.649\left(\mathrm{C}, \mathrm{CH}_{3}\right), 31\left(\mathrm{C}, \mathrm{CH}_{3}\right)$, 45.648 (C, C-OH), 106.387, 147.024 (6C, Ar-C), 151.176 (2C, $\mathrm{N}-\mathrm{C}=\mathrm{O}), 160.275(2 \mathrm{C}, \mathrm{N}-\mathrm{C}=\mathrm{O}), 166.711(\mathrm{C}, \mathrm{N}-\mathrm{C}=\mathrm{O})$. Elemental anal. calcd. (found) \% for $\mathbf{L}_{3}$ : C, 54.68 (52.70); H, 3.29 (3.48); N 17.72 (17.22).

Compound $\mathrm{L}_{4}$ : m.f. $\mathrm{C}_{27} \mathrm{H}_{19} \mathrm{O}_{5} \mathrm{~N}_{4} \mathrm{Cl}$, m.p. $102-105^{\circ} \mathrm{C}$, yield $76 \%$. IR (KBr, $\left.v_{\max }, \mathrm{cm}^{-1}\right): 3400$ (OH alcohol), 2919 and 2852 (C-H bend. $s p^{3}$ ), 1667 ( $\mathrm{C}=\mathrm{O}$ amide), 1486 and $1433(\mathrm{C}=\mathrm{C}$, arom.), 1286 (C-N str.), 696 (C-Cl bend.). ${ }^{1} \mathrm{H}$ NMR (300 MHz, TMS, $\delta$ ppm): 6.47 (s, H, OH), 1.30 (s, H, CH), 3.53 (s, 3H, N$\left.\mathrm{CH}_{3}\right), 6.99(\mathrm{~d}, 2 \mathrm{H}, \mathrm{CH}=\mathrm{CH}), 7.12,7.38,8.15(3 \mathrm{H}, \mathrm{Ar}-\mathrm{H}$ phenol.), 7.21, 7.48, 7.32 (3H, Ar-H with Cl), 7.34, 7.45, 7.44 (3H, Ar-H). ${ }^{13} \mathrm{C}$ NMR (300 MHz, TMS, $\delta$ ppm): $17.84(\mathrm{C}$, $\left.\mathrm{CH}_{3}\right), 20.56(\mathrm{C}, \mathrm{C}-\mathrm{Cl}), 45.50(\mathrm{C}, \mathrm{C}-\mathrm{OH}), 122.79,129.28$, 106.387, 147.024 (6C, Ar-C), 151.176 (2C, N-C=O), 160.275 $(2 \mathrm{C}, \mathrm{N}-\mathrm{C}=\mathrm{O}), 166.711(\mathrm{C}, \mathrm{N}-\mathrm{C}=\mathrm{O})$. Elemental anal. calcd. (found) \% for $\mathbf{L}_{4}$ : C, 62.97 (64.11); H, 3.69 (3.49); N 10.88 (9.12).

Homo-polymerization of synthesized drug substituted monomer ( $\mathbf{L}_{5}$ and $\left.\mathbf{L}_{6}\right)$ : In a dry polymer tube, a mode of monomer was prepared $(0.5 \mathrm{~g})$ and $15 \mathrm{~mL}$ of toluene and $(0.05 \mathrm{~g})$ of the initiator methyl ethyl ketone peroxide (MEKP) passed nitrogen gas for (10 min) after which the tube was sealed tightly and placed in a water bath at $90^{\circ} \mathrm{C}$ for $2 \mathrm{~h}$ when the polymerization is completed with the formation of precipitate. The precipitate was washed with ether and then dry in oven at $50^{\circ} \mathrm{C}$ [18] (Scheme-I).

Compound $\mathrm{L}_{5}$ : Colour: brown, IR $\left(\mathrm{KBr}, \nu_{\max }, \mathrm{cm}^{-1}\right): 3350$ (OH alcohol), 2981 and 2914 (C-H bend. $\left.s p^{3}\right), 1704(\mathrm{C}=\mathrm{O}$ in six membered imide ring), 1664 ( $\mathrm{C}=\mathrm{O}$ amide), 1553 and 1490 (C=C, arom.), 1288 (C-N str., phenyl ring). ${ }^{1} \mathrm{H} \mathrm{NMR} \mathrm{(300} \mathrm{MHz,}$ TMS, $\delta$ ppm): 6.50 (s, H, OH), 8.10, 7.70, 7.40 (3H, Ar-H), $9.80(\mathrm{~s}, \mathrm{H}, \mathrm{C}=\mathrm{CH}), 3.50\left(\mathrm{~s}, 3 \mathrm{H}, \mathrm{CH}_{3}\right), 3.30\left(\mathrm{~s}, 3 \mathrm{H}, \mathrm{CH}_{3}\right)$.

Compound $\mathrm{L}_{6}$ : Colour: Black, IR $\left(\mathrm{KBr}, v_{\max }, \mathrm{cm}^{-1}\right): 3400$ (OH alcohol), 2874 (C-H bend. $\left.s p^{3}\right), 1715(\mathrm{C}=\mathrm{O}$ in six membered imide ring), 1670 ( $\mathrm{C}=\mathrm{O}$ amide $), 1489$ and $1446(\mathrm{C}=\mathrm{C}$, arom.), 1288 (C-N str.), 552 (C-Cl bend.). ${ }^{1} \mathrm{H}$ NMR (300 MHz, TMS, $\delta$ ppm): $6.92(\mathrm{H}, \mathrm{OH}), 1.23(\mathrm{H}, \mathrm{CH}), 3.50\left(3 \mathrm{H}, \mathrm{N}-\mathrm{CH}_{3}\right)$, 
7.09-7.51 (H, Ar-H). ${ }^{13} \mathrm{C}$ NMR (300 MHz, TMS, $\delta$ ppm): 17.84

$\left(\mathrm{C}, \mathrm{CH}_{3}\right), 20.559(\mathrm{C}, \mathrm{C}-\mathrm{Cl}), 45.502(\mathrm{C}, \mathrm{C}-\mathrm{OH}), 122.789,129.284$,

106.387, 147.024 (6C, Ar-C), 151.176 (2C, N-C=O), 160.275

$(2 \mathrm{C}, \mathrm{N}-\mathrm{C}=\mathrm{O}), 166.711(\mathrm{C}, \mathrm{N}-\mathrm{C}=\mathrm{O})$.

Copolymerization of synthesized drug substituted mono$\operatorname{mer}\left(\mathbf{L}_{7}\right.$ and $\left.\mathbf{L}_{8}\right)$ : In a dry polymer tube a mode of monomer was prepared $(0.5 \mathrm{~g})$ and then added acrylic acid with the same number of moles of drug monomer and $15 \mathrm{~mL}$ of toluene and $(0.05 \mathrm{~g})$ of initiator methyl ethyl ketone peroxide (MEKP) passed the nitrogen gas for $10 \mathrm{~min}$, after which the tube was sealed tightly and placed in a water bath at $90^{\circ} \mathrm{C}$ for $2 \mathrm{~h}$, when the polymerization is completed with the formation of precipitate. The precipitate was washed with ether and then dry in oven at $50{ }^{\circ} \mathrm{C}$ [18] (Scheme-I).
Compound $\mathrm{L}_{7}$ : Colour: black, IR $\left(\mathrm{KBr}, \mathrm{v}_{\max }, \mathrm{cm}^{-1}\right)$ : 31362963 (OH carboxylic acid), 3300 (OH alcohol), 2963 (C-H bend. $\left.s p^{3}\right), 1708(\mathrm{C}=\mathrm{O}$ in six membered imide ring), $1665(\mathrm{C}=\mathrm{O}$ amide), 1553 (C=C, arom.), 1178 (C-N str.). ${ }^{1} \mathrm{H}$ NMR (300 MHz, TMS, $\delta$ ppm): 5.44 (H, OH), 6.90-8.20 (H, Ar-H), 8.60 $(\mathrm{H}, \mathrm{C}=\mathrm{CH}), 3.07\left(\mathrm{~s}, \mathrm{H}, \mathrm{CH}_{3}\right), 3.37(\mathrm{H}, \mathrm{CH}-\mathrm{COOH}), 10.35(\mathrm{H}$, $\mathrm{COOH})$.

Compound $\mathbf{L}_{\mathbf{8}}$ : Colour: dark brown, $\mathrm{IR}\left(\mathrm{KBr}, v_{\max }, \mathrm{cm}^{-1}\right)$ : (3460-2961) (OH carboxylic acid), 3100 (OH alcohol), 2961 (C-H bend. $\left.s p^{3}\right), 1719$ ( $\mathrm{C}=\mathrm{O}$ in six membered imide ring), 1618 ( $\mathrm{C}=\mathrm{O}$ amide), 1490 and 1450 ( $\mathrm{C}=\mathrm{C}$, arom.), 1284 (C-N str. $)$, 1035 (C-Cl bend.). ${ }^{1} \mathrm{H}$ NMR (300 MHz, TMS, $\delta$ ppm): 6.40 $(\mathrm{H}, \mathrm{OH}), 1.23\left(\mathrm{H}, \mathrm{CH}_{2}\right), 4.2\left(3 \mathrm{H}, \mathrm{N}-\mathrm{CH}_{3}\right), 6.50-8.51(\mathrm{H}, \mathrm{Ar}-\mathrm{H})$, $3.62(\mathrm{H}, \mathrm{CH}-\mathrm{COOH}), 10.37(\mathrm{H}, \mathrm{COOH})$.

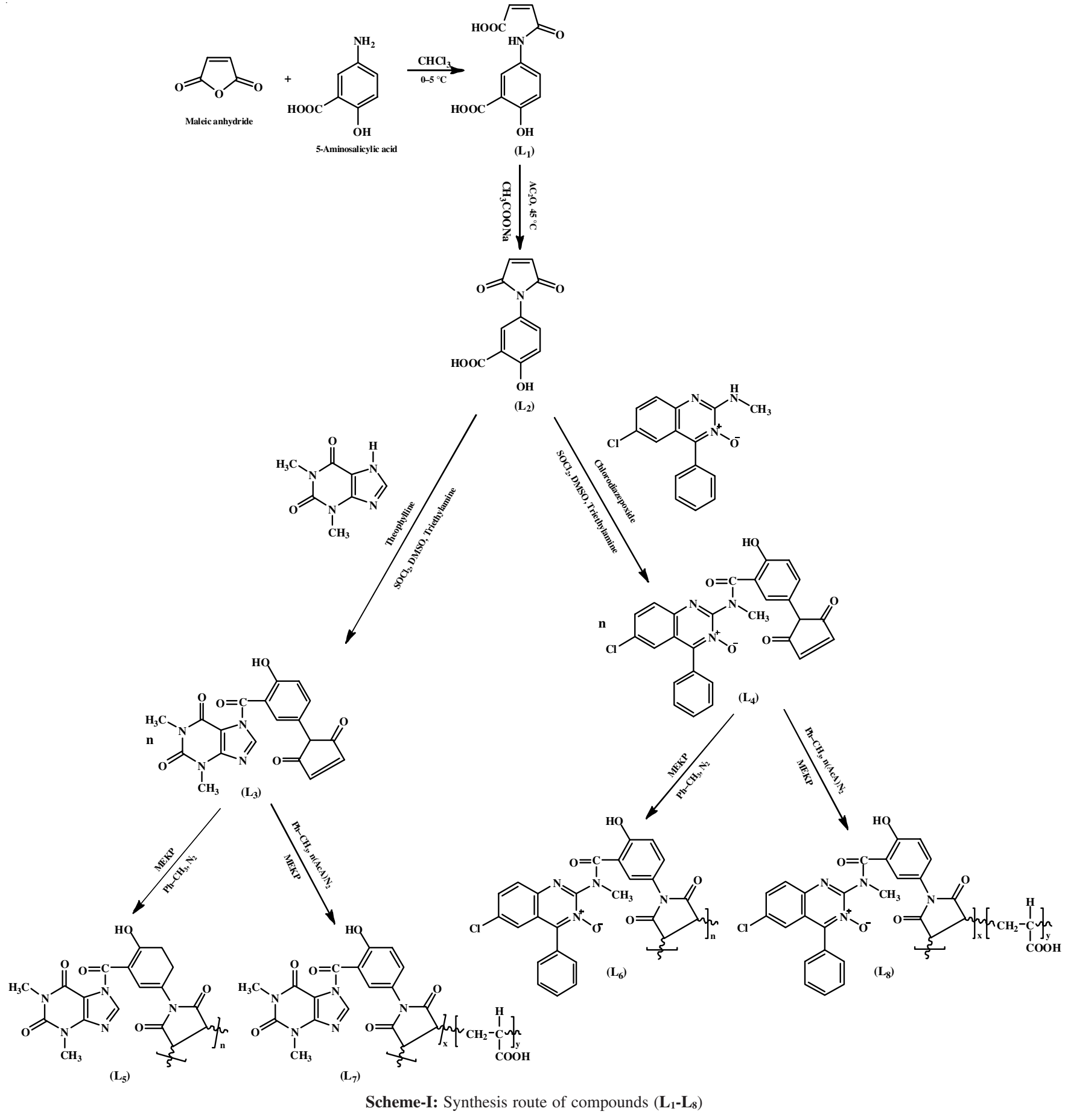


TABLE-2

SWELLING RATIO (\%) AND RELEASE OF DRUG FOR HOMOPOLYMER AND COPOLYMER AT pH $=2.2$ AND 8.0 AT $310 \mathrm{~K}$

\begin{tabular}{|c|c|c|c|c|c|c|c|c|c|c|c|c|c|c|c|c|}
\hline \multirow{3}{*}{$\begin{array}{l}\text { Time } \\
\text { (h) }\end{array}$} & \multicolumn{4}{|c|}{$\mathrm{L}_{5}$} & \multicolumn{4}{|c|}{$\mathrm{L}_{6}$} & \multicolumn{4}{|c|}{$\mathrm{L}_{7}$} & \multicolumn{4}{|c|}{$\mathrm{L}_{8}$} \\
\hline & \multicolumn{2}{|c|}{$\mathrm{pH}=2.2$} & \multicolumn{2}{|c|}{$\mathrm{pH}=8.0$} & \multicolumn{2}{|c|}{$\mathrm{pH}=2.2$} & \multicolumn{2}{|c|}{$\mathrm{pH}=8.0$} & \multicolumn{2}{|c|}{$\mathrm{pH}=2.2$} & \multicolumn{2}{|c|}{$\mathrm{pH}=8.0$} & \multicolumn{2}{|c|}{$\mathrm{pH}=2.2$} & \multicolumn{2}{|c|}{$\mathrm{pH}=8.0$} \\
\hline & $\%$ & Abs. & $\%$ & Abs. & $\%$ & Abs. & $\%$ & Abs. & $\%$ & Abs. & $\%$ & Abs. & $\%$ & Abs. & $\%$ & Abs. \\
\hline 1 & 0.5939 & 0.091 & 0.5864 & 0.483 & 0.8899 & 0.109 & 1.5858 & 0.851 & 0.1983 & 0.121 & 0.6106 & 0.354 & 1.7943 & 0.251 & 1.3757 & 0.665 \\
\hline 2 & 0.7501 & 0.130 & 0.8830 & 0.534 & 1.0395 & 0.139 & 1.6584 & 0.862 & 0.3993 & 0.151 & 0.7648 & 0.492 & 1.9192 & 0.259 & 1.5706 & 0.722 \\
\hline 3 & 0.9055 & 0.145 & 1.0211 & 0.654 & 1.1471 & 0.152 & 1.7807 & 0.893 & 0.5012 & 0.182 & 1.0648 & 0.541 & 2.1357 & 0.278 & 1.6981 & 0.798 \\
\hline 4 & 1.0185 & 0.172 & 1.4231 & 0.639 & 1.3081 & 0.181 & 2.4528 & 0.951 & 0.6980 & 0.199 & 1.2621 & 0.591 & 2.3453 & 0.301 & 1.9507 & 0.881 \\
\hline 5 & 1.2996 & 0.203 & 1.8553 & 0.601 & 1.5581 & 0.211 & 2.9583 & 0.998 & 0.8510 & 0.223 & 1.5558 & 0.732 & 2.5831 & 0.344 & 2.3973 & 0.999 \\
\hline
\end{tabular}

\section{Physical properties of polymers}

Solubility: Synthesized monomer, homopolymer and copolymers were highly soluble in acetone, DMSO, whereas partial or soluble in $\mathrm{H}_{2} \mathrm{O}$, ethanol, diethyl ether, toluene and chloroform indicating the presence of polar group.

Density and viscosity: The density of homopolymers and copolymer were determined at $25^{\circ} \mathrm{C}$ using densito 30px meter. Density values of homopolymers and copolymers are given Table-1. Viscosity determinations of 5-salicylic maleimide in acetone were carried out at the same concentration of homopolymer and copolymer in acetone at $25^{\circ} \mathrm{C}$ using an Ostwald viscometer with a capillary diameter of $0.49 \mathrm{~mm}$. The density, intrinsic viscosity and average molecular weight $\left(\mathrm{M}_{\mathrm{w}}\right)$ of the present polymer samples are listed in Table-1.

\begin{tabular}{ccc} 
TABLE-1 \\
\multicolumn{3}{c}{ PROPERTY OF VISCOSITY AND THE DENSITY } \\
OF PHARMACEUTICAL POLYMERS \\
\hline Compd. No. & Intrinsic viscosity $(\mathrm{dl} / \mathrm{g})$ & Density $\left(\mathrm{g} / \mathrm{cm}^{3}\right)$ \\
\hline $\mathbf{L}_{5}$ & 0.61 & 0.785 \\
$\mathbf{L}_{6}$ & 0.63 & 0.783 \\
$\mathbf{L}_{7}$ & 0.62 & 0.782 \\
$\mathbf{L}_{8}$ & 0.60 & 0.787 \\
\hline
\end{tabular}

Swelling and release: The rapid release of homo- $\left(\mathbf{L}_{5}\right.$ and $\left.\mathbf{L}_{6}\right)$ and copolymers $\left(\mathbf{L}_{7}\right.$ and $\left.\mathbf{L}_{8}\right)$ was studied. Acid and base functions were used where hydrolysis was gradual. As a pharmaceutical unit of the hydrolysis of polymers loaded with drugs when $\mathrm{pHs}=2.2$ and 8 . Table-2 shows the pharmacological release is progressively and concluded that at the end of process of drug liberation after $5 \mathrm{~h}$ and appeared that the drug release in the basal environment faster than the acid center, which is probably due to the attack at the nucleus of ion $\left(\mathrm{OH}^{-}\right)$. The carbon atom of carbonyl group is more stronger than proton $\left(\mathrm{H}^{+}\right)$or water molecule.

\section{RESULTS AND DISCUSSION}

Synthesis of a various drug delivery systems can provide the modifications and improve the therapeutic efficiency and safety of drugs. These may cause reduction in size and number of doses, side effects and biological inactivation and elimination. Also, the benefits may include lower toxicity and greater specificity of action.

The results on the variation of the double bond which is electron deficient bond occurring in the maleimide ring due to the presence of an electron withdrawing carbonyl group on both sides [5]. The maleimide double bond can be polymerized to give polymaleimides or it can be further polymerized, by addition of nucleophilic difunctional reagents, to give linear polymers.

It is also known that interlocking polymers have a solvent resistance because of the tangent that is specific to chain motion [19]. However polymerization is caused by the proliferation of solvent molecules in the polymer network within the crystalline network in the process of bloating in polymers with high molecular weight and volume changes causing polymer collapse during the process of mechanical stress through the process of bloating is known as the degree of polymer tangle, because the more the degree of entanglement challenged resistance to swelling and thus carried out the process of swelling of these polymers.

\section{Conclusion}

In this work, new drug substituted monomers and their new homogenous and heterogeneous polymers were synthesized which loaded with medical properties to extended the controlled drug. Homogeneous polymers $\left(\mathbf{L}_{5}\right.$ and $\left.\mathbf{L}_{6}\right)$ prepared through polymerization reaction of free radicals of monomers $\left(\mathbf{L}_{1}\right.$ and $\left.\mathbf{L}_{2}\right)$ under nitrogen using MEKP as initiator. Heterogeneous polymers $\left(\mathbf{L}_{7}\right.$ and $\left.\mathbf{L}_{\mathbf{8}}\right)$ prepared through polymerization reaction of free radicals of the monomers $\left(\mathbf{L}_{3}\right.$ and $\left.\mathbf{L}_{4}\right)$ separately with acrylic acid under nitrogen using methyl ethyl ketone peroxide as initiator. All these prepared monomers and polymers were characterized by FTIR and ${ }^{1} \mathrm{H}$ NMR, ${ }^{13} \mathrm{C}$ NMR spectroscopies. Controlled drug release and swelling $\%$ was studied in different $\mathrm{pHs}$ values at $37^{\circ} \mathrm{C}$.

\section{CONFLICT OF INTEREST}

The authors declare that there is no conflict of interests regarding the publication of this article.

\section{REFERENCES}

1. D.K. Hood and O.M. Musa, eds.: O.M. Musa, Application of Maleic Anhydride in Coatings, Adhesives and Printing, In: Handbook of Maleic Anhydride Based Materials, Springer (2016).

2. N.G. Gaylord, J. Macromol. Sci., 13C, 235 (1975); https://doi.org/10.1080/15321797508080011.

3. M.M. Sharabash and R.L. Guile, J. Macromol. Sci., 10A, 1017 (1976); https://doi.org/10.1080/00222337608061233.

4. N.G. Gaylord and M. Mehta, J. Polym. Sci., 20C, 481 (1982); https://doi.org/10.1002/pol.1982.130200903.

5. S. Edge, A. Charlton, K.S. Varma, T.K. Hansen, P. Kathirgamanathan, A.E. Underhill, J. Becher and O. Simonson, Synth. Metals, 53, 315 (1993); https://doi.org/10.1016/0379-6779(93)91101-7.

6. K. Onimura, M. Matsushima, K. Yamabuki and T. Oishi, Polym. J., 42, 290 (2010);

https://doi.org/10.1038/pj.2009.341.

7. D. Fles, R. Vukovic, A.E. Kuzmic, G. Bogdanic, V. Pilizota, D. Karlovic, K. Markus, K. Wolsperger and and D. Vikic-Topi, Croat. Chem. Acta, 76, 69 (2003). 
8. V.G. Kadajji and G.V. Betageri, Polymers, 3, 1972 (2011); https://doi.org/10.3390/polym3041972.

9. B. Dhandayuthapani, Y. Yoshida, T. Maekawa and D.S. Kumar, Int. J. Polym. Sci., Article ID 290602 (2011); https://doi.org/10.1155/2011/290602.

10. R. Duncan, Nat. Rev. Drug Discov., 2, 347 (2003); https://doi.org/10.1038/nrd1088.

11. S.J. Patil and P.J. Shirote, Int. J. Med. Pharm. Sci., 1, 1 (2011).

12. K. Hoste, K. De Winne and E. Schacht, Int. J. Pharm., 277, 119 (2004); https://doi.org/10.1016/j.ijpharm.2003.07.016.

13. T. Etrych, P. Chytil, M. Jelinkova, B. Rihova and K. Ulbrich, Macromol. Biosci., 2, 43 (2002);

https://doi.org/10.1002/1616-5195(20020101)2:1<43::AID-MABI43> 3.0.CO; $2-8$.
14. T. Etrych, M. Jelinkova, B. Rihova and K. Ulbrich, J. Control. Rel., 73, 89 (2001); https://doi.org/10.1016/S0168-3659(01)00281-4.

15. A. Weissberger, Physical Methods of Organic Chemistry, Interscience: New York, vol. I, Part-I, Ch. 4, p. 149 (1985).

16. A.K. Obaid, M.M. Kareem, S.A. Aowda and A.K. Raju, Int. J. ChemTech Res., 9, 398 (2016).

17. A.E. Hoyt and B.C. Benicewicz, J. Polym. Sci., Polym. Chem. Ed., 28, 3403 (1990); https://doi.org/10.1002/pola.1990.080281218.

18. S.H. Awad, A.A. Alrazak, F.H. Mohammed and A.M. Hasan, J. Univ. Babylon Pure Appl. Sci., 26, 148 (2018).

19. C. Ferrero, D. Massuelle and E. Doelker, J. Control. Rel., 141, 223 (2010);

https://doi.org/10.1016/j.jconrel.2009.09.011. 